\title{
The Effect of Knowledge Management on Innovation and Organizational Performance in The Field of Application and Game Development
}

\begin{abstract}
Simon Budiprayitno

Faculty of Economics and Business, University of

Brawijaya, Malang, Indonesia simonbudiprayitno@ymail.com

This research examines the effect of knowledge management on innovation and organizational performance (Case Study on Creative Industries in the field of Application and Game Development in Malang Raya). Looking at the existing phenomena clearly shows that most creative industries still show a lot of room for improvement regarding their innovation and business performance and the lack of application of knowledge management in creative industries compared to large organizations. Data collection methods in this study include field research that is by collecting necessary data (primary data) from a sample using a questionnaire instrument that explains and tests hypotheses (explanatory) and uses literature studies derived from literature and scientific journals. The results of this study are that management knowledge has a significant effect on innovation and performance. Innovation has a significant effect on performance and that knowledge management has a significant effect on performance through innovation Changes in performance are primarily determined by the high ability of innovation due to the creative industry players have increased the ability in knowledge management.
\end{abstract}

Keywords: knowledge management; innovation; performance

\section{INTRODUCTION}

Knowledge Management (KM) is seen as necessary, because its implementation and implementation benefits the operations and services, can improve personal competence, maintain the availability of knowledge and innovation and product development. Intentional and systematic coordination of people, technology, processes and organizational structures to add value through reuse and innovation. This coordination is achieved by creating, sharing, and applying knowledge and by giving valuable lessons learned and best practices into corporate memory to encourage sustainable organizational learning (Dalkir, 2011). 
Improved performance supported by KM practices in organizations has been proposed by Stankosky (2005) which shows that successful KM implementation requires the integration of the four pillars of $\mathrm{KM}$, namely leadership, learning, organizational structure, and technology. These KM factors are tools to improve the performance of both public and private organizations.

Knowledge management is also very influential in organizational innovation. Knowledge can be used as input for the innovation process. Knowledge does not only rely on natural resources but also resources of knowledge, ideas and creativity. Changes in the environment also require organizations to be more proactive and innovative. Innovation is considered an essential mechanism for becoming more competitive and for survival in the global business world. According to Scholl in Yeşil, Koska, \& Büyükbeşe (2013) states that if there is no innovation, then no one can talk about growth and competitiveness.

At present, all large organizations and creative industries also need the application of knowledge management to improve their performance and innovation. The role of knowledge management on organizational performance is enormous. Currently, almost all large organizations apply knowledge management in improving organizational performance and innovation, while in the creative industries there are still a few and still rarely apply knowledge management in improving performance and innovation so that the creative industries become less competitive with large organizations.

Looking at the previous phenomena, this shows clearly that most creative industries still show a lot of room for improvement regarding their innovation and business performance and the lack of application of knowledge management in creative industries compared to large organizations. Therefore, researchers want to know whether the knowledge management system affects innovation and organizational performance, especially in the creative industries.

This paper aims to study the correlation between knowledge management with innovation and performance. Data collection methods in this study include field research that is by collecting necessary data (primary data) from a sample using a questionnaire instrument that explains and tests hypotheses (explanatory) and uses literature studies derived from literature and scientific journals.

\section{THEORETICAL REVIEW}

Knowledge management is an effort to produce value from an organization's intellectual property through the creation, storage, distribution, and application of knowledge to achieve organizational goals. In detail, experts' opinions regarding the definition of knowledge management according to Liebowitz (1999) knowledge management is the formalization of access to experience, the knowledge that can create new capabilities, superior performance, increase innovation and customer value. According to Wigg in Liebowitz (1999) knowledge management is a systematic, slow development, renewal and application of knowledge to maximize the effectiveness of organizational knowledge and the benefits of knowledge assets. 
Groff and Jones (2003) say knowledge management is a tool, technique, strategy for storing, analyzing, organizing, improving and sharing business experience. According to Greiner, Bohmann, \& Krcmar (2007) Knowledge management includes all the activities that utilize knowledge to accomplish the organizational objectives in order to face the environmental challenges and stay competitive in the market place

\section{Knowledge Management Indicator}

Knowledge management in this research is defined as managing company knowledge in creating business value and producing sustainable competitive advantages by optimizing the process of creating, communicating and applying all the knowledge needed as a significant part of achieving business goals Tiwana in Sagirani et al. (2012). In this study knowledge management is measured using three indicators according to Sagirani et al., 2012), namely: knowledge acquisition (X1.1) is the process of developing and constructing insights, skills and relationships; knowledge sharing $(\mathrm{X} 1.2)$ is a process that includes the dissemination of knowledge; knowledge utilization (X1.3) is the use of knowledge which is usually useful if the learning process has been integrated with the organization; knowledge protection (X1.4) is the process of securing knowledge assets and storing them safely and is accessed only by authorized personnel; disseminate Knowledge (X1.5) knowledge must be available in a format that is useful for organizations when and where they are needed.

\section{Organizational Performance Indicators}

Performance indicators are quantitative and qualitative measures that describe the level of achievement of goals/objectives (Bastian, 2001) that have been determined to take into account the following elements of the indicator: inputs are everything needed for an organization to be able to produce its products, both goods or services which include human resources, information, and policies; outputs are something that is expected to be directly achieved from an activity that is physical or non-physical; results (outcomes) are all things related to the ultimate goal of the implementation of activities; impacts are the effects caused by both positive and negative indicator levels based on the assumptions that have been set; in discussing organizational performance, it is always discussed and distinguished about private organizations and public organizations. The indicators used to measure organizational performance between private and public can also be said to be categorically different. To distinguish a particular organization is a private organization or public organization, there are also indicators.

\section{Understanding Performance}

Performance is the work that can be achieved by a person or group of people in an organization under their respective authority and responsibilities in order to achieve organizational goals within a specified period (Prawirosentono, 2012). Moreover, there is a close relationship between individual performance with organizational performance. In other words, if employee performance is excellent, likely, organizational performance is also good. Performance is also translated as a description of the level of achievement of the implementation of an activity/program/policy in realizing the goals, objectives, 
mission and vision of the organization contained in the strategic planning of an organization (Mahsun, 2009).

\section{Organizational Performance Indicators}

Performance indicators are quantitative and qualitative measures that describe the level of achievement of goals/objectives (Bastian, 2001) which have been determined to take into account the following elements of the indicator: Inputs are everything needed for an organization to be able to produce its products, both goods or services which include human resources, information, and policies; outputs are something that is expected to be directly achieved from an activity that is physical or non-physical; results (outcomes) are all things related to the ultimate goal of the implementation of activities; impacts are the effects caused by both positive and negative indicator levels based on the assumptions that have been set.

\section{Definition and Characteristics of Innovation}

According to Stephen Robbins, innovation is as a new idea that is applied to initiate or improve a product or process and service. Based on this understanding, Robbins focuses more on three main things, namely: A new idea is a thought in observing a phenomenon that is happening, including in the field of education, this new idea can be a discovery of an idea, ideas, systems to the possibility of crystallized ideas; products and services, which are the results of further steps from new ideas that are followed up with various activities, studies, research and experiments produce more concrete concepts in the form of products and services that are ready to be developed and implemented, including the results of innovation in education.

\section{Knowledge Management and Innovation}

Innovative efforts include the search for, and discovery, experimentation, and development of new technologies, new products or services, new production processes, and new organizational structures. The consequences of this business are sometimes seen as raw materials for the information industry. The new management philosophy realizes that information is the result of the evolution of knowledge and that a robust network between intellectual endeavour and technological innovation is increasingly expanding. Innovative efforts are also an appropriate consequence of knowledge worker and knowledge investment. If the search for innovation positively influences KM, investment in developing new knowledge can encourage organizations to enter new businesses in more satisfying markets.

Innovation must be seen as a complex process, which involves a series of investment possibilities. In this investment perspective, knowledge must be considered as a kind of capital. For this reason, the development process is a managerial problem because it can lead to new product launches. The success of an innovative product is closely related to research activities and orientation changes. On the other hand, these two elements depend on the development of knowledge levels and the innovative efforts of knowledge workers. 


\section{METHODOLOGY}

Data collection methods in this study include field research that is by collecting primary data (primary data) from a sample using a questionnaire instrument that explains and tests hypotheses (explanatory) and uses literature studies derived from literature and scientific journals. Data analysis in this study uses a quantitative approach which classifies, calculates, compares and analyzes data. Analysis of the data in this study was divided into six stages. The first stage is descriptive statistical analysis, the second stage is inferential statistical analysis, the third stage is testing data quality, and the fourth stage is testing hypotheses.

\section{RESEARCH RESULTS}

\section{Characteristics of Respondents in Research}

Research data obtained from questionnaires that have been distributed to respondents. The number of respondents involved in this study amounted to 174 people. Respondent characteristics in this study consisted of gender, age and education level.

Table 1. Frequency Distribution of Respondent Characteristics

\begin{tabular}{lll}
\hline Characteristics & Amount & Percentage (\%) \\
\hline Gender & 133 & 76,4 \\
Male & 41 & 23,6 \\
Female & 174 & 100,0 \\
Total & & \\
& & \\
Age & 92 & 52,9 \\
$18-22$ years old & 29 & 16,7 \\
$>22-$ 27 years old & 20 & 11,5 \\
$>27$-32 years old & 33 & 19,0 \\
$>32$ years od & 174 & 100,0 \\
A & & \\
& & \\
Education & 54 & 31,0 \\
Senior High School & 47 & 27,0 \\
Diploma III & 53 & 30,5 \\
Diploma IV/S1 & 20 & 11,5 \\
Masters Degree & 174 & 100,0 \\
Total & & \\
\hline
\end{tabular}

Measured knowledge management variables from 13 items have scored in the range 27 65 with an average of 52.15 (higher than the median score $=39$ ). The results of the assessment of knowledge management variables illustrate that most creative industry players have responded positively to various indicators of knowledge management. Measured innovation variables of 10 items have a score with a range of 21-50 with an average of 29.25 (smaller than the median value $=30$ ). The results of the evaluation of the innovation variables illustrate that most creative industry players do not respond positively to various indicators of innovation. Measured performance variables of 9 
items have scored in the range 19-45 with an average of 34.80 (higher than the median value $=27$ ). The results of the performance appraisal illustrate that most creative industry players have responded positively and are already high performing.

Table 2. Descriptive Statistics of Research Variables

\begin{tabular}{lllllll}
\hline Variable & Item & $\begin{array}{l}\text { Score } \\
\text { Range }\end{array}$ & Median & Minimum Maximum & Average \\
\hline X1. Knowledge & 13 & $13-65$ & 39 & 27 & 65 & 52,15 \\
Management & 10 & $10-50$ & 30 & 21 & 50 & 29,25 \\
Y1. Innovation & 9 & $9-45$ & 27 & 19 & 45 & 34,80 \\
Y2. Performance & 9 & & & &
\end{tabular}

Table 3. Recapitulation of the results of the validity and reliability test

\begin{tabular}{|c|c|c|c|c|c|c|}
\hline \multirow{2}{*}{ Item } & \multicolumn{2}{|c|}{ Correlation coefficient } & \multirow{2}{*}{ Information } & \multicolumn{2}{|c|}{ Alpha Cronbach } & \multirow{2}{*}{ Information } \\
\hline & Early & End & & Early & End & \\
\hline $\mathrm{X} 11.1$ & 0,718 & 0,718 & Valid & 0,835 & 0,835 & Reliable \\
\hline $\mathrm{X} 11.2$ & 0,718 & 0,718 & Valid & & & \\
\hline $\mathrm{X} 12.1$ & 0,513 & 0,513 & Valid & 0,738 & 0,738 & Reliable \\
\hline $\mathrm{X} 12.2$ & 0,605 & 0,605 & Valid & & & \\
\hline $\mathrm{X} 12.3$ & 0,572 & 0,572 & Valid & & & \\
\hline $\mathrm{X} 13.1$ & 0,648 & 0,648 & Valid & 0,776 & 0,776 & Reliable \\
\hline $\mathrm{X} 13.2$ & 0,585 & 0,585 & Valid & & & \\
\hline $\mathrm{X} 13.3$ & 0,629 & 0,629 & Valid & & & \\
\hline $\mathrm{X} 14.1$ & 0,621 & 0,621 & Valid & 0,844 & 0,844 & Reliable \\
\hline $\mathrm{X} 14.2$ & 0,799 & 0,799 & Valid & & & \\
\hline $\mathrm{X} 14.3$ & 0,772 & 0,772 & Valid & & & \\
\hline $\mathrm{X} 15.1$ & 0,783 & 0,783 & Valid & 0,878 & 0,878 & Reliable \\
\hline$X 15.2$ & 0,783 & 0,783 & Valid & & & \\
\hline Y11.1 & 0,661 & 0,661 & Valid & 0,770 & 0,770 & Reliable \\
\hline Y11.2 & 0,548 & 0,548 & Valid & & & \\
\hline Y11.3 & 0,606 & 0,606 & Valid & & & \\
\hline Y12.1 & 0,688 & 0,688 & Valid & 0,893 & 0,893 & Reliable \\
\hline $\mathrm{Y} 12.2$ & 0,817 & 0,817 & Valid & & & \\
\hline Y12.3 & 0,809 & 0,809 & Valid & & & \\
\hline Y12.4 & 0,769 & 0,769 & Valid & & & \\
\hline Y13.1 & 0,665 & 0,665 & Valid & 0,795 & 0,795 & Reliable \\
\hline$Y_{13.2}$ & 0,665 & 0,665 & Valid & & & \\
\hline Y21.1 & 0,504 & 0,504 & Valid & 0,638 & 0,638 & Reliable \\
\hline$Y 21.2$ & 0,504 & 0,504 & Valid & & & \\
\hline Y22.1 & 0,738 & 0,738 & Valid & 0,841 & 0,841 & Reliable \\
\hline$Y 22.2$ & 0,738 & 0,738 & Valid & & & \\
\hline$Y 23.1$ & 0,792 & 0,792 & Valid & 0,856 & 0,856 & Reliable \\
\hline$Y 23.2$ & 0,792 & 0,792 & Valid & & & \\
\hline$Y 24.1$ & 0,424 & 0,609 & Valid & 0,548 & 0,757 & Reliable \\
\hline$Y 24.2$ & 0,245 & - & Not Valid & & & \\
\hline$Y 24.3$ & 0,437 & 0,609 & Valid & & & \\
\hline
\end{tabular}

190 Management and Economics Journal (MEC-J)

Vol 4 (2) August 2020 


\section{Test Results Validity and Reliability of Research Instruments}

Item validity was tested by calculating the corrected product-moment correlation coefficient. If this coefficient is more than 0.30 , then the item is valid, whereas Cronbach's Alpha coefficient measures the reliability.

At the exposure to the results, there are two parts, namely the beginning and end where all items on all indicators of knowledge management and innovation all have validity and reliability that meet the requirements. Whereas on the performance variable, only the evaluation of the fourth indicator in the second item has a correlation coefficient of 0.245 so it cannot be used as a valid measuring item on the indicator. Overall, the items used in this study were 32 items that had validity and reliability that met the requirements, namely the correlation coefficient ranged from 0.504 to 0.817 (more than 0.30 ) and the reliability coefficient ranged from 0.738 to 0.893 (more than 0.60 ).

Table 4. Check Linear Assumptions

\begin{tabular}{lccccc}
\hline \multirow{2}{*}{ Relation } & \multicolumn{2}{c}{ Linearity } & \multicolumn{2}{c}{ Deviation } & \\
& from Linieirty & Information \\
& $\mathbf{F}$ & $\mathbf{P}$ & $\mathbf{F}$ & $\mathbf{P}$ & \\
\hline $\begin{array}{l}\text { Knowledge management }- \\
\text { Innovation }\end{array}$ & 11,291 & 0,001 & 0,997 & 0,428 & Linear \\
$\begin{array}{l}\text { Knowledge management - } \\
\text { Performance }\end{array}$ & 40,056 & 0,000 & 1,044 & 0,393 & Linear \\
Innovation ->Performance & 40,137 & 0,000 & 0,173 & 0,994 & Linear \\
\hline
\end{tabular}

The linearity assumption in path analysis is only related to structural equation modelling and is not related to hypothesis testing, i.e. the relationship between variables in the structural model is linear. Linearity results explain that all paths meet the linearity assumption if the $F$ test results in the linearity section are significant $(p<0.05)$. There are supporting test results in other parts, namely deviation from linearity, which aims to test whether the linearity that is fulfilled is also supported by the low suitability of the model for non-linear relationships. If the deviation from linearity test results is not significant ( $p>0.05$ ), it means that the relationship between the two variables is indeed linear. This analysis concludes that the linearity requirements have been fulfilled in all paths in the hypothesis model. On the linearity test results, the $F$ test results are significant $(p<0.05)$. 


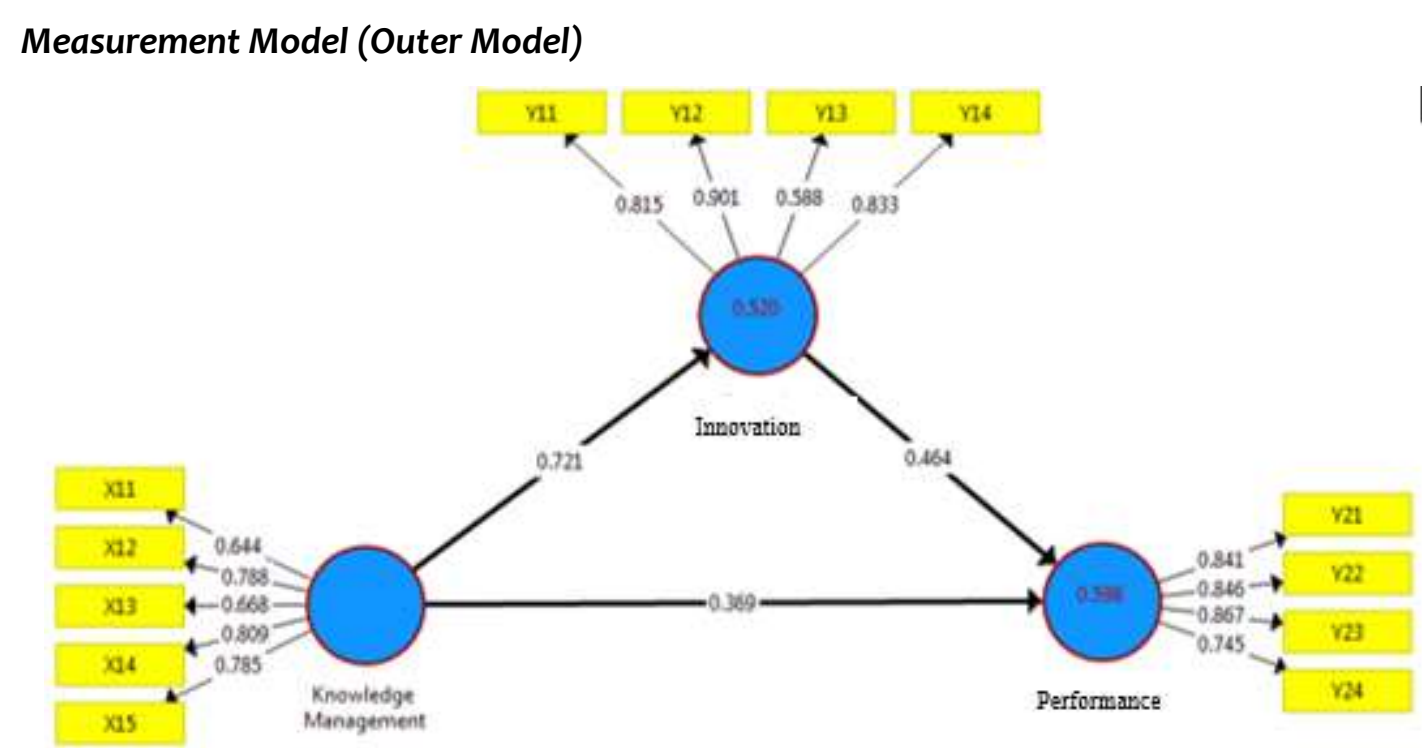

Figure 1. Initial Outer Model

Outer model or measurement model is an assessment of the validity and reliability of research variables. The results of the analysis on the outer model (Figure 1 ), all indicators have a loading factor of more than 0.50 , which explains that the construct validity of each indicator meets the requirements. There are three criteria to assess the outer model, namely convergent validity, discriminant validity, and composite reliability.

\section{Convergent Validity Test}

Convergent validity measures the validity of an indicator as a measure of the construct, which can be seen from outer loading. The indicator is considered valid if it has an outer loading value of 0.5 to 0.6 is considered sufficient; the number of indicators per construct is not large, ranging from 3 to 7 indicators. Validation based on loading factors on all indicators is proper because it is worth more than 0.5 . All indicators have a loading factor of more than 0.50 are also the highest value in the construct when compared to cross-loading in other constructs.

Validation based on loading factors on all indicators is proper because it is worth more than 0.5 . All indicators have a loading factor more than 0.50 are also the highest value in the construct when compared to cross-loading in other constructs. Outer model evaluation based on loading factor and cross-loading is included in both categories. Discriminant validity uses the square root of the average extracted (VAVE). If the root value of AVE for each latent variable is higher than the correlation with other variables, then the instrument is said to have good discriminant validity, as shown in Table 7. 
Table 5. Loading Factor

\begin{tabular}{lclc}
\hline Variable & Indicator & \multicolumn{1}{c}{ Label } & Loading Factor \\
\hline Knowledge & X1.1 & Knowledge Acquisition & 0.644 \\
Management & X1.2 & Knowledge Utilization & 0.788 \\
X1.3 & Knowledge Sharing & 0.668 \\
X1.4 & Knowledge Protection & 0.809 \\
X1.5 & Disseminate Knowledge & 0.785 \\
Y1.1 & Invention & 0.815 \\
Innovation & Y1.2 & Development & 0.901 \\
& Y1.3 & Duplication & 0.588 \\
Y1.4 & Synthesis & 0.833 \\
Performance & Y2.1 & Inputs & 0.841 \\
& Y2.2 & Outputs & 0.846 \\
Y2.3 & Outcomes & 0.867 \\
Y2.4 & Impacts & 0.745 \\
\hline
\end{tabular}

Table 6. Loading Factor and Cross Loading

\begin{tabular}{lccc}
\hline Indicator & Innovation & Performance & Knowledge Management \\
\hline $\mathrm{X}_{11}$ & 0.558 & 0.440 & $\mathbf{0 . 6 4 4}$ \\
$\mathrm{X}_{12}$ & 0.606 & 0.546 & $\mathbf{0 . 7 8 8}$ \\
$\mathrm{X} 13$ & 0.383 & 0.469 & $\mathbf{0 . 6 6 8}$ \\
$\mathrm{X} 14$ & 0.566 & 0.568 & $\mathbf{0 . 8 0 9}$ \\
$\mathrm{X} 15$ & 0.537 & 0.574 & $\mathbf{0 . 7 8 5}$ \\
Y11 & $\mathbf{0 . 8 1 5}$ & 0.565 & 0.543 \\
Y12 & $\mathbf{0 . 9 0 1}$ & 0.699 & 0.731 \\
Y13 & $\mathbf{0 . 5 8 8}$ & 0.377 & 0.389 \\
Y14 & $\mathbf{0 . 8 3 3}$ & 0.619 & 0.567 \\
Y21 & 0.649 & $\mathbf{0 . 8 4 1}$ & 0.637 \\
Y22 & 0.566 & $\mathbf{0 . 8 4 6}$ & 0.582 \\
Y23 & 0.652 & $\mathbf{0 . 8 6 7}$ & 0.623 \\
Y24 & 0.532 & $\mathbf{0 . 7 4 5}$ & 0.463 \\
\hline
\end{tabular}

Table 7. Results of Discriminant Validity

\begin{tabular}{lllll}
\hline Construct & AVE & Innovation & Performance & $\begin{array}{l}\text { Knowledge } \\
\text { Management }\end{array}$ \\
\hline Innovation & 0.629 & 0.793 & & \\
Performance & 0.682 & 0.730 & 0.826 & \\
Knowledge & 0.551 & 0.721 & 0.703 & 0.742 \\
management & & & \\
\hline
\end{tabular}


The coefficients on the diagonal section are the roots of AVE; The coefficient outside the diagonal is the correlation coefficient between constructs; AVE = Average Variance Extracted. A measurement model fulfils discriminant validity if the roots of AVE of a construct are higher than the correlation coefficient with other constructs. For example, the construct of innovation has an AVE value of 0.629, an AVE root of 0.79 is obtained. The correlation coefficient of the innovation construct with other constructs ranges from 0.551 to 0.682 , so this analysis concludes that there is a relatively good discriminant validity.

\section{Composite Reliability Test}

Composite reliability tests the reliability value between the indicators of the construct that constitutes it. The construct is declared excellent and reliable if the composite reliability value is above 0.70 (Ghozali, 2008). The results of testing the reliability of measurement models can be presented in Table 8 below.

Table 8. Composite Reliability results

\begin{tabular}{lccl}
\hline Construct & AVE & $\begin{array}{c}\text { Composite } \\
\text { Reliability }\end{array}$ & Results \\
\hline Knowledge management & 0.551 & 0.859 & Reliable \\
Innovation & 0.629 & 0.869 & Reliable \\
Performance & 0.682 & 0.895 & Reliable \\
\hline
\end{tabular}

The reliability test results showed that all constructs had a composite reliability coefficient of more than 0.70 . Thus, all measurement models used in this study already have high reliability. So that further analysis can be done by examining the model's goodness of fit by evaluating the inner model.

\section{Structural Model Testing (Inner Model)}

The testing of the inner model aims to find out the path coefficient and the inner Tstatistic model, which shows the level of significance of the change in the independent variable on the dependent variable. 


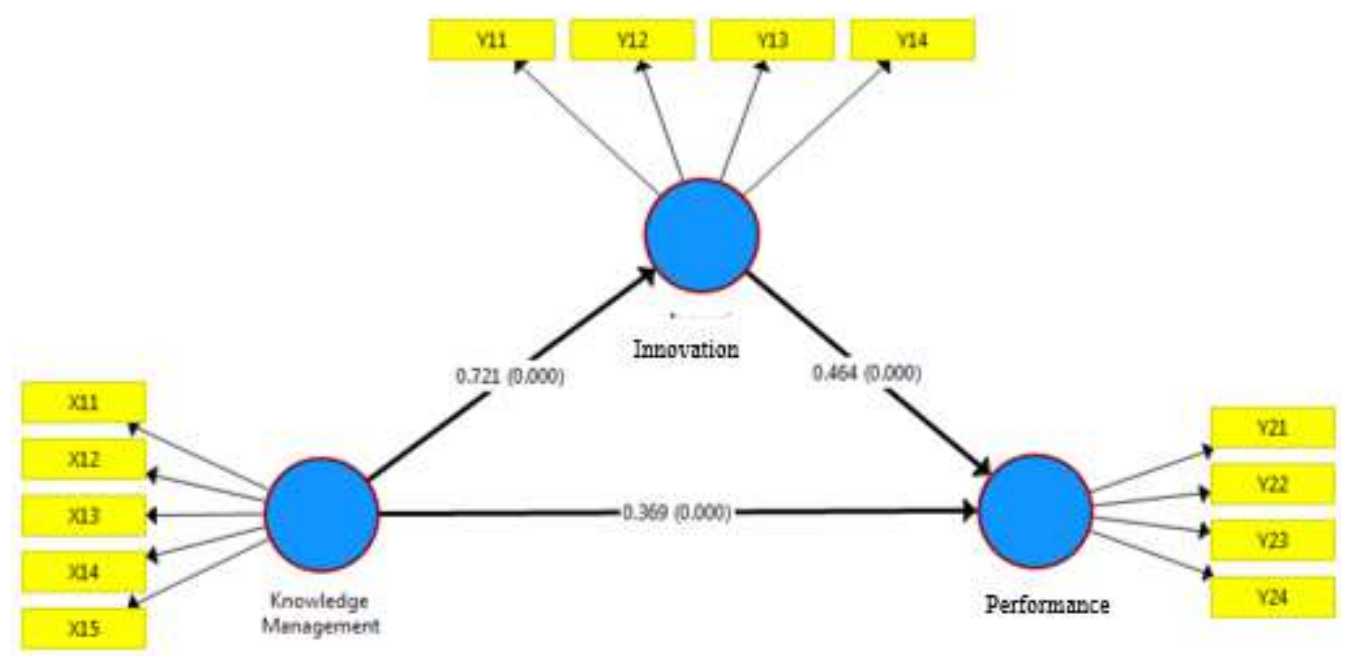

Figure 2. Path Coefficient Test Results

Table 9. Test Results for the Path Coefficient on the Inner Model

\begin{tabular}{lcccc}
\hline Relationship & $\begin{array}{c}\text { Path } \\
\text { coefficient }\end{array}$ & $\begin{array}{c}\text { Standard } \\
\text { Error }\end{array}$ & Statistics t & P \\
\hline $\begin{array}{l}\text { Knowledge management -> } \\
\text { Innovation }\end{array}$ & 0.721 & 0.047 & $15.372^{*}$ & 0.000 \\
$\begin{array}{l}\text { Knowledge management -> } \\
\text { Performance }\end{array}$ & 0.369 & 0.078 & $4.752^{*}$ & 0.000 \\
Innovation -> Performance & 0.464 & 0.071 & $6.530^{*}$ & 0.000 \\
\hline
\end{tabular}

The interpretation of the tables and figures explains the relationship between variables as follows: (1). Knowledge management of innovation has a coefficient in a positive direction. The calculation results show that the path coefficient of 0.721 with a t-statistic of $15.273(p=0.000)$ provides a decision that knowledge management has a significant effect on innovation. (2). Knowledge management on performance has a coefficient in a positive direction. The calculation results show that the path coefficient of 0.369 with a t-statistic of $4.752(p=0.000)$ gives the decision that knowledge management has a significant effect on performance. (3). Innovation on performance has a coefficient in a positive direction. The calculation results show that the path coefficient of 0.464 with a t-statistic of $6.50(p=0,000)$ provides a decision that innovation has a significant effect on performance.

\section{Indirect and Total Effects}

In the relationship to performance, the enormous total influence is on the relationship of knowledge management with a value of 0.703 . This result can be interpreted that knowledge management variables have a strategic role that is indirect through innovation, increasing the performance of creative industry players. 
Table 10. Direct, Indirect and Total Effect Results

\begin{tabular}{|c|c|c|c|c|c|}
\hline $\begin{array}{c}\text { Correlation } \\
\text { variable }\end{array}$ & & Direct & Indirect & Total & $\mathrm{p}$ \\
\hline $\begin{array}{l}\text { Knowledge } \\
\text { management }\end{array}$ & Innovation & 0.721 & - & 0.721 & 0.000 \\
\hline $\begin{array}{l}\text { Knowledge } \\
\text { management }\end{array}$ & Performance & 0.369 & 0.335 & 0.703 & 0.000 \\
\hline Innovation & Performance & 0.464 & - & 0.464 & 0.000 \\
\hline
\end{tabular}

Significance test results of the indirect effect of knowledge management on performance through innovation proved to be significant $(p<0.05)$.

\section{Hypothesis Testing Results}

The $\mathrm{H} 1$ hypothesis states that alleged knowledge management has a significant effect on innovation. This hypothesis will be related to the test results of the coefficient of the direct influence of knowledge management on innovation. The calculation results show that the path coefficient of knowledge management $(b=0.721 ; p=0,000)$ gives the decision that there is a significant influence on innovation. Then the results of this test explain that $\mathrm{H} 1$ is supported.

The $\mathrm{H}_{2}$ hypothesis states that alleged knowledge management has a significant effect on performance. This hypothesis will be related to the test results of the coefficient of the direct influence of knowledge management on performance. The calculation results show that the path coefficient of knowledge management $(b=0.369 ; p=0,000)$ gives the decision that there is a significant influence on performance. Then the results of this test explain that $\mathrm{H} 2$ is supported.

The $\mathrm{H}_{3}$ hypothesis states that alleged innovation has a significant effect on performance. This hypothesis will be related to the test results of the coefficient of the direct influence of innovation on performance. The calculation results show that the path coefficient of innovation $(b=0.464 ; p=0,000)$ gives the decision that there is a significant influence on performance. Then the results of this test explain that $\mathrm{H}_{3}$ is supported.

Hypothesis $\mathrm{H}_{4}$ states that alleged knowledge management has a significant effect on performance through innovation. The calculation results show that the indirect influence of knowledge management on performance through innovation $(b=0.335 ; p=0,000)$ is significant. Then the results of this test explain that $\mathrm{H}_{4}$ is supported

\section{DISCUSSION}

\section{Knowledge Management Influences Innovation}

Based on research data processing for the knowledge management variable measured by 13 items, the average value obtained for the knowledge management variable is 3.99 (good or high category). This means that employees feel strong knowledge 
management in the creative industries of application and game development. The knowledge management indicator which is perceived to be the highest average value is the knowledge protection indicator with an average value of 4.15. In contrast, the knowledge management indicator that has the lowest average is the knowledge acquisition indicator with an average value of 3.73 (good or high category).

From the results of this study, the first hypothesis proves that knowledge management has a significant effect on innovation. The results of this study are in line with research by (du Plessis, 2007). In the opinion of (du Plessis, 2007) that the results of this study indicate that in today's fast-changing business world, innovation has become a mainstay of the organization. The nature of global economic growth has been changed by the speed of innovation, which is made possible by rapidly developing technology, shorter product life cycles and higher levels of new product development. The complexity of innovation has increased with the growing amount of knowledge available to organizations. The point is that by increasing knowledge management in organizations, there will be increased innovation by the organization. Based on the acceptance of the first hypothesis, it shows that knowledge management has a significant effect on innovation in the creative industry of application and game development.

\section{Knowledge Management influences performance.}

Based on research data processing for the knowledge management variable measured by 13 items, the average value obtained for the knowledge management variable is 3.99 (good or high category). This means that employees feel strong knowledge management in the creative industries of application and game development. The knowledge management indicator which is perceived to be the highest average value is the knowledge protection indicator with an average value of 4.15. In contrast, the knowledge management indicator that has the lowest average is the knowledge acquisition indicator with an average value of 3.73 (good or high category).

From the results of this study, the second hypothesis proves that knowledge management has a significant effect on performance. The results of this study are in line with the research of (Yousif \& Shahizan, 2013). In the opinion of (Yousif \& Shahizan, 2013) that the results of this study indicate that knowledge management strategies have a statistically significant and direct positive effect on innovation and organizational performance. Most remarkable, the results show that knowledge management strategies have a positive and statistically significant effect on organizational performance through the partial mediating effect of innovation. The point is that by increasing existing knowledge management in organizations, the higher the performance produced. Based on the acceptance of the second hypothesis, it shows that knowledge management has a significant effect on performance in the creative industries of application and game development.

\section{Innovation influences performance}

Based on the processing of research data for the innovation variables measured by ten items obtained an average value for the innovation variable 3.89 (good or high 
category). This means that employees feel a substantial innovation in the creative industries of application and game development. The innovation indicator, which is perceived to be the highest average value is the development indicator with an average value of 4.04. In contrast, the innovation indicator that has the lowest average is the duplication indicator with an average value of 3.66 (good or high category).

From the results of this study, the third hypothesis proves that innovation has a significant effect on performance. The results of this study are in line with research by Crema, Verbano, \& Venturini (2014). According to Crema, Verbano, \& Venturini (2014) that the results of this study indicate that organizations that pursue innovative strategies are those who invest more in technical skills and core competencies. Organizations that choose diversification strategies tend to use exclusively open innovation managerial practices, while organizations that focus on efficiency strategies tend to apply open innovation practices and to a lesser extent, to the development of core competencies. The point is by increasing innovation in organizations. It can also improve organizational performance. Based on the acceptance of the third hypothesis, it shows that innovation has a significant effect on performance in the creative industries of application and game development.

\section{Knowledge Management influences performance through innovation.}

Based on research data processing for the knowledge management variable measured by 13 items, the average value obtained for the knowledge management variable is 3.99 (good or high category). This means that employees feel strong knowledge management in the creative industries of application and game development. The knowledge management indicator which is perceived to be the highest average value is the knowledge protection indicator with an average value of 4.15. In contrast, the knowledge management indicator that has the lowest average is the knowledge acquisition indicator with an average value of 3.73 (good or high category).

From the results of this study, the fourth hypothesis proves that knowledge management has a significant effect on performance through innovation. The results of this study are in line with research Jin et al. (2015). In the opinion of Jin et al. (2015) research that the results of the study this shows that the knowledge base is an essential foundation for improving a company's innovation performance. More detailed analysis reveals that the breadth of first knowledge provides more benefits for explorative innovation performance while the depth of knowledge is more beneficial for the exploitative innovation performance of an organization. Second, organizational looseness can positively facilitate increased depth of knowledge for exploratory innovation performance while an optimal balance of breadth and depth of knowledge can significantly improve exploitative innovation performance. The point is by increasing knowledge management it will affect performance improvement through high innovation support. Based on the acceptance of the fourth hypothesis, it shows that knowledge management has a significant effect on performance through innovation in the creative industries of application and game development. 


\section{CONCLUSION}

Knowledge management has a positive effect on innovation in the creative industries of application and game development. The positive influence shows that the higher the knowledge management obtained, the higher the innovation that is carried out. An then knowledge management has a positive effect on performance in the creative industries of application and game development. The positive influence shows that the higher the knowledge management obtained, the higher the performance produced. The third innovation has a positive effect on performance in the creative industries of application and game development. The positive influence shows that the higher the innovation carried out, the higher the performance produced. Finally, knowledge management has a positive effect on performance through innovation in the creative industries of application and game development. These positive influences indicate that the higher the knowledge management gained, the higher the performance generated through mediating innovation.

The results of this study are expected to provide benefits. They can be used as a reference, information and useful input for leaders and employees in an organization, especially the creative industry in the field of application and game development in Malang Raya in implementing its policies so that innovation and industrial performance better. The researcher realizes that this study has the following research limitations: limited time in researching so that the population and sample studied are limited; limitations in accessing the data of respondents who were specifically studied; Lack of interaction or interviews directly with the respondents studied.

\section{REFERENCES}

Bastian, I. (2001). Sistem Akuntansi Sektor Publik. Ed. 2. Jakarta: Salemba Empat

Crema, M., Verbano, C., \& Venturini, K. (2014). Linking strategy with open innovation and performance in SMEs. Measuring Business Excellence, 18(2), 14-27. https://doi.org/10.1108/MBE-07-2013-0042

Dalkir, K. (2011). Knowledge Management in Theory and Practice (2nd ed.). Journal of the American Society for Information Science and Technology, 62. https://doi.org/10.1002/asi.21613

Du Plessis, M. (2007). The role of knowledge management in innovation. Journal of Knowledge Management, 11(4), 20-29. https://doi.org/10.1108/13673270710762684

Ghozali, I. (2008). Structural Equation Modeling Metode Alternatif dengan Partial Least Square. Edisi Kedua. Badan Penerbit Universitas Diponegoro. Yogyakarta

Groff, T. R., \& Jones, T. P. (2003). Introduction to knowledge management: KM in business. Burlington, MA: Butterworth Heinemann.

Greiner, M. E., Bohmann, T., \& Krcmar, H. (2007). A strategy for knowledge management. Journal of Knowledge Management, 11(6), 3-15. https://doi.org/10.1108/13673270710832127

Liebowitz. J. (1999). The Handbook of Applied Expert Systems. https://doi.org/10.1201/9780138736654 
Mahsun, M. (2009). Pengukuran kinerja sektor public. (edisi ke-20). Yogyakarta: BPFE.

Prawirosentono. (2012). Manajemen Sumber Daya Manusia. Jakarta: Bumi Aksara

Sagirani, R. T. B. M. J. D. S. Tri, S. (2012). Rancang bangun aplikasi knowledge management multimedia dalam proses pengembangan video pendidikan pada bpmtv surabaya.

Stankosky, M. A. (2005). Advances in Knowledge Management: University Research Toward an Academic Discipline. Creating the Discipline of Knowledge Management. https://doi.org/10.1016/b978-0-7506-7878-0.50005-3

Yeşil, S., Koska, A., \& Büyükbeşe, T. (2013). Knowledge Sharing Process, Innovation Capability and Innovation Performance: An Empirical Study. Procedia - Social and Behavioral Sciences, 75, 217-225. https://doi.org/10.1016/j.sbspro.2013.04.025

Yousif, L.A.A \& Hassan, S. (2013). Knowledge management strategies, innovation, andorganisational performance. Journal of Advances in Management Research, 10 (1), $58-71$

Jin, X., Jie, W., Song, C., Ting, W. (2015). A study of the relationship between the knowledgebase and the innovation performance under the organizational slack regulating. Management Decision, 53(10), 2202-2225 